一側顔面痤攣症に括けるアブミ骨筋の病態

\author{
戸島均・青柳優・稲村 博雄 \\ 小池 吉郎・板垣 晋一*. 中井 昂*

\section{Neurophysiological Studies on Stapedius Muscle in Patients with Hemifacial Spasm}

\author{
Hitoshi Tojima, Masaru Aoyagi, Hiroo Inamura, \\ Yoshio Koike, Shin-ichi Itagaki and Osamu Nakai \\ (Yamagata University)
}

\begin{abstract}
Hemifacial spasm (HFS) is characterized by involuntary contructions of the mimetic muscles, and it is usually accompanied by synkinesis. When spasm and synkinesis spread to the stapedius muscle, tympanic noise (tinnitus due to the stapedius muscle contruction) arise. In the present study, 57 patients with HFS who had normal tympanogram and stapedius reflex were examined by impedance audiometry to determine the spasm and synkinesis of the stapedius muscle before and after microvascular decompression. Only 18 patients complained of tympanic noise, but 54 showed the stapedius muscle spasm and synkinesis. After operation, in all cases tynpanic noise disappeared and 50 patients showed neither spasm nor synkinesis of the stapedius muscle. During the operation, 5 of these patients were also recorded by electrical stimulation on supraorbital nerve using needle electrodes inserted through the external auditory meatus. Synkinetic responses of the stapedius muscles could be recorded in 4 cases, and these abnormal potentials disappeared after intraoperative procedures. These results suggests that spasm and synkinesis spreads to the stapedius muscle even in patients without tynpanic noise, and these disappear during the microvascular decompression operation.
\end{abstract}

Key words: hemifacial spasm, stapedius muscle, synkinesis, tympanic noise, microvascular decompression

はじめに

一側顔面痙卛症 (hemifacial spasm, HFS) は, 一側表情筋の不随意で不規則な収縮である. 典 型的な HFS は, 通常下眼輪筋の軽い㾏攣で始 まり, 徐々に広頸筋を含めた一側表情筋全体に 広がるとともに, 痤攣の強さや持続時間が増し,
間代性痙攣から強直性痙攣となる。また HFS では痙攣のない時においても，ある1つの表情 筋を収縮させようとすると同側の他の表情筋も 共に収縮するといら病的共同運動が存在する事 も知られている. 最近 HFS は顔面神経が脳幹 起始部で血管により圧迫を受けて起こる事が明 
らかになりこの血管による压迫を手術的に解 除する microvascular decompression (MVD) が 広く行われるようになった ${ }^{1)}$.この MVD 術後 には症攣のみならず病的共同運動が共に消失す る.この事は, HFS のこの $2 つ の$ 病的現象が ともに血管による神経の圧迫により起こってい る事を示しているが，その発症機序は未解決で ある。

一方, 顔面神経は表情筋以外にアブミ骨筋を 支配している。痤攣と病的共同運動という HFS に打ける 2 つ症候はこのアブミ骨筋に も及び，痤攣や表情運動の際にゴソゴソとかガ サガサといら耳雑音（アブミ骨筋性耳鳴）を自 覚する症例がある。そこで我々は HFS 患者に おけるアブミ骨筋の病態を明らかにするために, 一連の HFS 患者にたいし MVD 術前後にイン ピーダンスオージオィトリーによるアブミ骨筋 の症攣，病的共同運動の記録を行うと共に，一 部の症例については術中記録を試みた。また耳 雑音を感じる症例の頻度を明らかにし，その雑 音の成因についての考察を加えた。

\section{対象と方法}

対象は昭和58年11月から平成 2 年12月までに 山形大学医学部脳神経外科六 61例のらち，MVD 術前後㑢膜穿孔がなく子 ィンパノグラムが $\mathrm{A}$ 型でかつアブミ骨筋反射が 正常であった57例である。そのらち5例に対し MVD 術中検査を行った。

MVD 術前後に执けるアブミ骨筋の痤攣，病 的共同運動の記録には, Amplaid 702インピー ダンスオージオメータを用いた。まずチィンパ ノグラムが $\mathrm{A}$ 型で，アブミ骨筋反射が正常であ る事を確認した後に，顔面痤攣時あるいは閉眼 や口笛運動時のコンプライアンスの変化を記録 した。同時に眼輪筋，口輪筋の表面電極による 筋電図をDANTEC Evomatic 2000で記録した。 MVD 術前, 術後 2 週以内に本検査を行った. 術後 2 週で軽度の顔面神経麻痺がありアブミ骨 筋反射が認められなかった症例や，疰攣が弱い ながらも残存した症例は，それぞれ1から 3 力
月後に麻痺が治癒しアブミ骨筋反射が正常化し た後，あるいは㽷攣の消失を確認してから検査 した。

MVD 術中の検査は全身麻酔後, 眼輪筋反射 を記録するために刺激電極としての板電極を上 眼窩孔上の皮膚上に固定し，眼輪笳に同芯針電 極を刺入した。さらに，アブミ骨筇電位を記録 するために図 1 に示すよらな先端のみを露出し た針電極を外耳道後壁から鼓膜を通してアブミ 骨筋近くに扣き関電極とし，不関電極として同 様の針電極を䛅角に刺入（図 2 )，2 本の電極

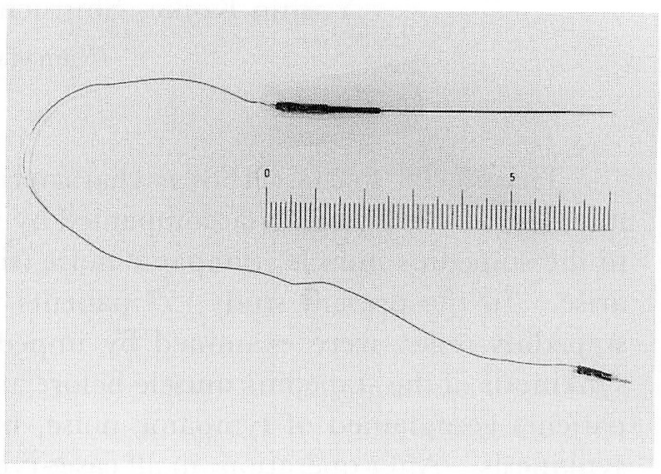

図 1 アブミ骨筋用の電極(ステンレス製で先端 を除きエナメルで被覆した)。

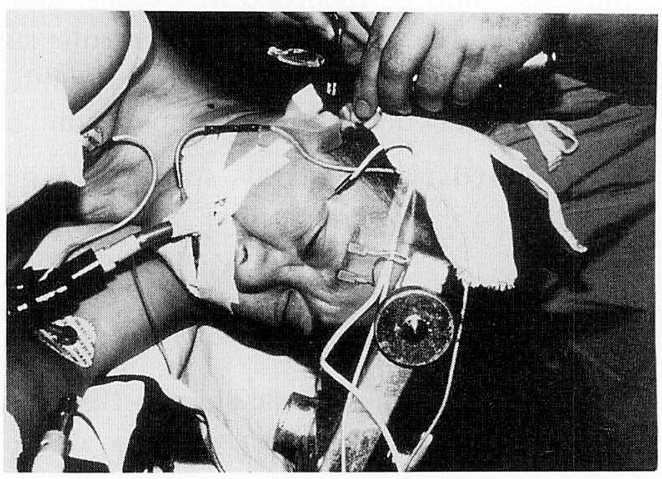

図 2 右 HFS 患者に対する術中筋電図モニター のために, 頭部 3 点固定後上眼窩神経刺 激のための板電極, 眼輪笳に同芯針電極 を設置後, アブミ゙骨筋への電極を耳垢針 子にて刺入しているところ. 写真には才 トガイ筋にも同芯針電極を刺入してある が，本論文では無関係である。 
は外耳道にアロンアルファにて固定した。 さら にこれら電極が移動しないように患側顔面をド レープで被った．上眼窩神経を $0.2 \mathrm{~ms}$ の矩形 波で電気刺激し, 眼輪筋反射電位とともにアブ ミ骨筋の電位（病的共同運動電位）を同時に記 録した. MVD 術中この検査を頻回に行い, ア ブミ骨筋病的共同運動電位の手術操作による消 失時期について検討した。なお，麻酔は気管内 挿管時にのみ筋弛緩剤を用いて以後は使用せず, かつ手術操作前には筋弛緩剤の効果が無くなつ ていることを確認した.

\section{結 果}

1. HFS に打けるアブミ骨筋の病攣，病的 共同運動と，アブミ骨筋性耳雑音について（図 $3,4,5$, 表 1$)$

HFS 患者でアブミ骨筋性耳雑音を伴った症 例は57例中18例 $(32 \%)$ であった。これら患者 に中耳インピーダンスを測定すると，健側では， 表情運動時にコンプライアンスの変化は無いが, 患側では, 痙攣や表情運動に一致してコンプラ イアンスの低下を認めた。これは, 痤攣や病的 共同運動がアブミ骨筋に及び，その収縮により コンプライアンスが低下するものと考光られた。 このような痙攣や病的共同運動に伴う異常な中 耳コンプライアンスの低下は，耳雑音を自覚し た症例18例全例に認められたのみならず，耳雑 音を自覚しない39例中 36 例 $(92 \%)$ にも認めら れた。この事は，耳雑音を自覚しない症例の多 くにも痓攣や病的共同運動がアブミ骨筋に及ん でいると考えられた．MVD 術後には，この耳 雑音を自覚した18例全例が，耳雑音の消失とと もに表情運動に伴う中耳ュンプライアンスの異 常な低下が消失した，耳雑音を自覚しなかった 症例で，アブミ骨筋の病的共同運動が認められ た36例中32例（89\%）に表情運動に伴う中耳ュ ンプライアンスの異常な低下が消失し， 2 例が 著しい減弱， 2 例が不変であった。 その男女比, 左右比, 年齢差, 罹病期間の比較, 術中確認し た圧迫血管の種類を検討したが，耳雑音の有無 で有意の差はなかった。
2.MVD 術中の検査結果（図 6, 7, 表 2) MVD 術前にインピーダンスオージオメトリー によりアブミ骨筋の病的共同運動を認めた 4 例

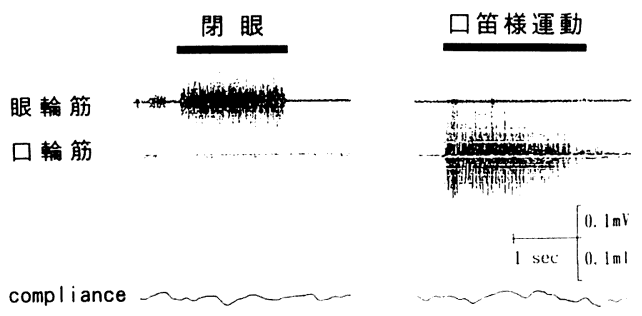

図 3 正常側の筋電図とインピーダンスオージオ人 トリーによる表情筋とコンプライアンスの同 時記録

閉眼時には眼輪筋，口笛様運動時には口輪筋の夕が 収縮し、コンプライアンスの変化は起こらない。

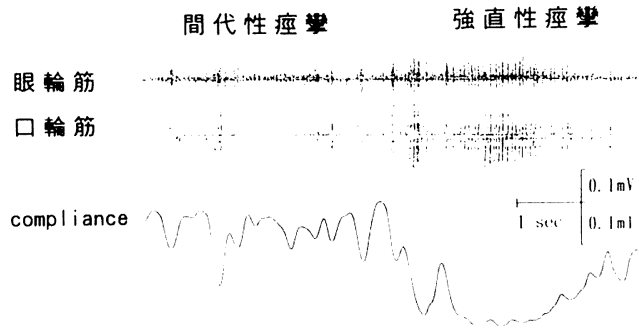

図 4 患側痙戀時の記録

間代性痤攣時には眼輪筋，口輪筋の収縮とコンプ ライアンスの低下は同期して起こり, 強直性痙樂 時にはコンプライアンスは持続的に低下する.

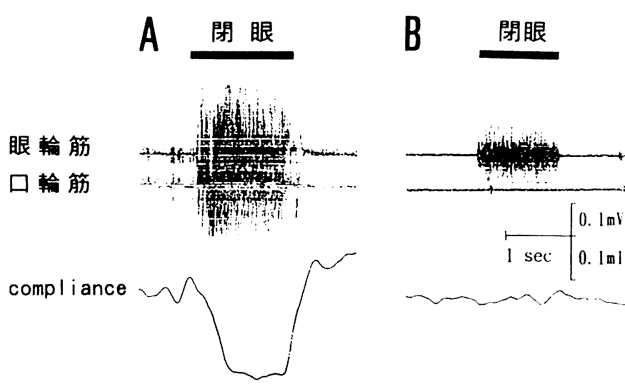

図 5 患側の MVD 術前 $(\mathrm{A})$, 術後 $(\mathrm{B})$ の記録 術前に閉眼させると眼輪筋の収縮に同調して口輪 笳の収縮やコンプライアンスの低下が認められる (病的共同運動)。術後にはこの病的共同運動は消 失する. 
と認めなかった 1 例に対し術中記録を行った。

手術操作開始直前の上眼窩神経を電気刺激した ときの眼輪筋の誘発電位は 5 例全例に記録され 潜時は 10.7〜13.6 ms であった. アブミ骨筋の 誘発電位は術前にアブミ骨筋の病的共同運動が 存在した 4 例にのみ記録でき，潜時は 6.5〜 $11.2 \mathrm{~ms}$ で眼輪筋電位より $2.4 \sim 4.5 \mathrm{~ms}$ 短い潜 時で出現し，振幅は $2.4 \sim 3.6 \mu \mathrm{V}$ であった. 術前にアブミ骨筋の病的共同運動が認められな かった症例 5 では，アブミ骨筋の誘発電位は記 録できなかった。

術中操作による眼輪筋，アブミ骨筋の誘発電 位の変化を経時的に記録してみると，症例 1 で
は硬膜切開, 脳䯣液吸引時にアブミ骨筋誘発電 位が消失し，かつその後に眼輪筋誘発電位も消 失した。残り 3 例に执いても，直接血管を減圧 するよりも前の操作（小脳圧排時 2 例，クモ膜 切開剝離時 1 例）でアブミ骨筋電位は症例 1 と 同様に消失した。これらの症例の術後には，痤 攣と病的共同運動が表情筋のみならずアブミ骨 筋に㘯いても消失し，かつ顔面神経麻痺もなく アブミ骨筋反射は正常であった。

\section{考察}

HFS は通常下眼輪筋の痙攣で始まり, 数力 月後には広頸筋を含めた一側表情筋全体の痙攣 となる，痙攣の強さとともに持続時間も増し，

表 1 耳雑音の有無による症例の比較

\begin{tabular}{|c|c|c|c|c|}
\hline & 耳雑音（+） & 耳雑音（－） & 合 & 計 \\
\hline 症 例 数 & $18(32 \%)$ & $39(68 \%)$ & \multicolumn{2}{|c|}{57} \\
\hline アブミ骨筋の & 術 前 18 例 & 術 前 36例 & 術前 & 術後消失 50 例 \\
\hline $\begin{array}{c}\text { 痙攣, 病的共同運動 } \\
\text { 男/女 }\end{array}$ & $\begin{array}{c}\text { 術後消失 } 18 \text { 例 } \\
4 / 14\end{array}$ & $\begin{array}{c}\text { 術後消失 } 32 \text { 例 } \\
15 / 24\end{array}$ & \multicolumn{2}{|c|}{$19 / 38$} \\
\hline 右/左 & $8 / 10$ & $16 / 23$ & \multicolumn{2}{|c|}{$24 / 33$} \\
\hline 年 & $\begin{array}{c}28 \sim 66 \\
\text { (平均50.9歳) }\end{array}$ & $\begin{array}{c}35 \sim 77 \\
\text { (平均 } 57.0 \text { 歳) }\end{array}$ & \multicolumn{2}{|c|}{$\begin{array}{c}28 \sim 77 \\
\text { (平均 } 55.0 \text { 歳) }\end{array}$} \\
\hline 罹 病 期 間 & $\begin{array}{c}1 \sim 15 \text { 年 } \\
\text { (平均 } 4.8 \text { 年) }\end{array}$ & $\begin{array}{c}4 \text { 月 31年 } \\
\text { (平均 5.7年) }\end{array}$ & \multicolumn{2}{|c|}{$\begin{array}{c}\text { 4月〜31年 } \\
\text { (平均 5.3年) }\end{array}$} \\
\hline 責任 血管 & & & & \\
\hline AICA & 13（1） & $24(5)$ & \multicolumn{2}{|c|}{$37(6)$} \\
\hline PICA & $3(0)$ & $13(2)$ & \multicolumn{2}{|c|}{$16(2)$} \\
\hline VA & $3(1)$ & $6(3)$ & \multicolumn{2}{|c|}{$9(4)$} \\
\hline $\mathrm{BA}$ & 0 & $1(0)$ & \multicolumn{2}{|c|}{$1(0)$} \\
\hline
\end{tabular}

AICA : 前下小脳動脈 PICA : 後下小脳動脈 VA：椎骨動脈 BA: 脳底動脈 （）は重複例で, AICA+VA：4 例 AICA+PICA：2 例

表 2 術中記録結果

\begin{tabular}{|c|c|c|c|c|c|c|c|c|c|c|}
\hline \multirow{2}{*}{ 症例 } & \multirow{2}{*}{ 齢 } & \multirow{2}{*}{ 性 } & \multirow{2}{*}{$\begin{array}{l}\text { 羅病期間 } \\
\text { (年) }\end{array}$} & \multirow{2}{*}{ 耳雑音 } & \multirow{2}{*}{$\begin{array}{l}\text { 術前のアブミ骨筋 } \\
\text { の病的共同運動 }\end{array}$} & \multicolumn{2}{|c|}{ アブミ骨筋 } & \multirow{2}{*}{$\begin{array}{c}\text { 眼輪筋 } \\
\text { 潜 時 } \\
\text { ms }\end{array}$} & \multirow{2}{*}{$\begin{array}{l}\text { アブミ骨筋電位 } \\
\text { の消失時期 }\end{array}$} & \multirow{2}{*}{ 王迫血管 } \\
\hline & & & & & & 潜時 ms & 振幅 $\mu \mathrm{V}$ & & & \\
\hline 1 & 40 & $\mathrm{~F}$ & $1 y$ & + & + & 7.5 & 3.6 & 10.7 & 硬膜切開 & PICA \\
\hline 2 & 66 & M & $1 y$ & - & + & 9.8 & 2.8 & 12.7 & 小脳圧排 & AICA \\
\hline 3 & 47 & $\mathrm{~F}$ & $2 y$ & - & + & 11.2 & 2.4 & 13.6 & 小脳王排 & AICA \\
\hline 4 & 45 & $\mathrm{~F}$ & $3 y$ & - & + & 6.5 & 2.4 & 11.0 & クモ膜切開 & AICA \\
\hline 5 & 44 & $\mathrm{~F}$ & $1 y$ & - & - & - & - & 10.7 & & PICA \\
\hline
\end{tabular}


発作性の間代性㾏攣から強值性疘攣が見られる ようになる，HFS に対する MVD 手術効果は 根治的治療法とい光る程確実かつ永続的であ り1), HFS の原因が顔面神経脳幹起始部におけ る血管の圧迫である事を疑ら余地は無い，村上 らの報告2)では，顔面神経核から出た顔面神経 の運動神経線維は, 神経束内での specific organization が無く，表情筋各筋やアブミ骨筋 を支配する神経線維がばらばらに分布すると言 われているＨFS の原因が脳幹起始部である ならば，表情筋の痤攣や病的共同運動は同時に アブミ骨筋にも起こっているはずであり，かつ MVD の術中，術後に消失するはずである。し かし，アブミ骨筋の痤攣や病的共同運動につい ての当科領域でのまとまった報告は意外に少な い。この事を, MVD 術前, 中, 後に証明寸る のが本論文の目的である.

HFS において患側のみにしかも痤攣や表情 運動に一致してガサゴソとかブーンブーンとい

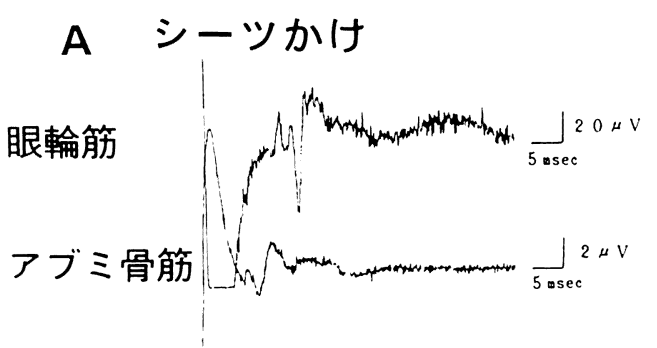

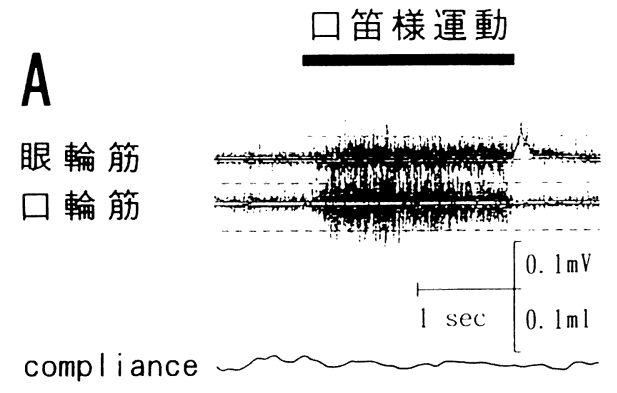

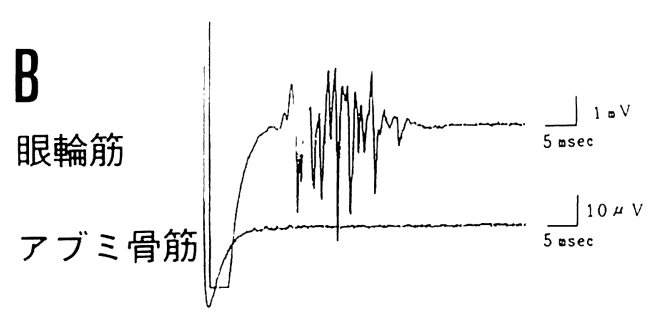

図 7 術前に眼輪筋と口輪筋には病的共同運動が 認められたが，アブミ骨筋の病的共同運動 が涩められなかった $(\mathrm{A})$ 症例 万では, 術中 にもアブミ，骨筋の病的共同運動電位は記録 できなかった(B).

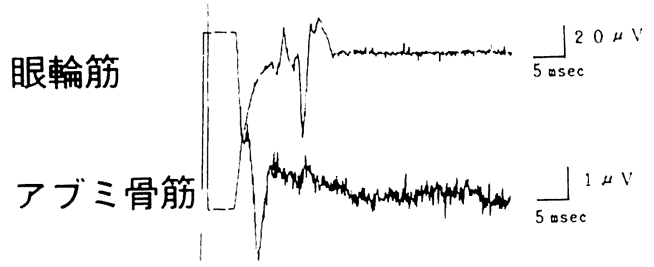

D 硬膜切開、脳脊随液吸引

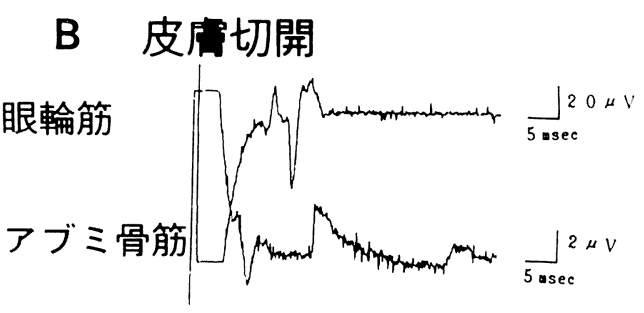

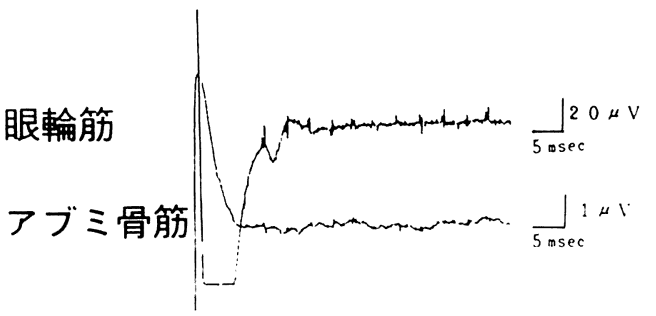

図 6 MVD 術中の BR による眼輪筋, アブミ骨筋の病的共同運動記録

眼輪筋の潛時 $(10.7 \mathrm{~ms})$ より $3.2 \mathrm{~ms}$ 短い暂時でアブミ骨筋の病的基同運動電位が記録された。手術操作に伴 ら変化を経時的に記録すると骨空削開までは眼輪筋とアブミ骨筋の電位は記録できたが, 硬膜切開後脳䯣液 を吸引するとアブミ骨筋電位が消失, 眼輪筋電位も小さくなり (D) その後消失した. 
ら低音性の耳鳴がアブミ骨筋性耳鳴の特徴であ る. 本論文ではこれを耳雑音と呼ぶことにした。 HFS 患者57例中, この耳雑音を自覚する症例 は18例（32\%）であった。これは金ら3)の32\% （47例中15例）と極めて近い頻度である.HFS は女性に多く（男：女 19:38）, 左に多かっ

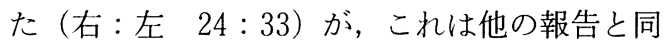
じである.耳雑音の有無で患者を分けて比較し ても，女性でかつ左側に多いことにはかわりな かった。ささらに年齿と罹病期間についてみても， 有意の差はなかったが，耳雑音を訴えた患者は 若く罹病期間が短い傾向にあり, 雑音の出現が 痙攣の重症度とは関係がないと考えられた。

アブミ骨筋の収縮は，アブミ骨の可動性を抑 制するよらに働き中耳伝音系のインピーダンス が増強しコンプライアンスが低下する．よって インピーダンスオージオメトリーを用いると, アブミ骨筋の痙攣や病的共同運動はコンプライ アンスの低下として検出できる。その際留意す べき注意点は, 痤攣や表情運動により耳介や外 耳道が変形し，それに起因するみせかけの（偽 りの）コンプライアンスの変動である.これを 除外するために以下のような事に注意している. 1) 骨部外耳道まで適切な大きさの probe を 挿入, 密着させること, 2) 肉眼的に probe が表情運動や痤孚により動かない事を確認する こと，3）外耳道圧を $100 \mathrm{mmH}_{2} \mathrm{O}$ まで高めた 時には, 㾏攣や病的共同運動に伴らコンプライ アンスの低下を認めないか著しく減弱すること, 4 ）健側ではコンプライアンスの変動が無いこ と，である．以上のことに注意すれば，アブミ 骨筋の病的共同運動や痙攣はコンプライアンス の低下として的確に判定できると考える.

以上の方法でアブミ骨筋に痙攣や病的共同運 動が及んでいると判定できた症例は54例(95\%) であった、耳雑音を自覚した症例では全例に, 耳雑音を自覚しない例でも $92 \%$ に認められたこ とは, 耳雑音の有無にかかわらずアブミ骨筋に も痤攣や病的共同運動が起こっていることを示 している.この結果は, 金らの報告3) とほぼ同
じで, 顔面神経アブミ骨筋枝より中枢側に病変 が存在することと矛盾しない。

MVD 術中のアブミ骨筋の病的共同運動の変 化をとらえるために，アブミ骨筋電位をモ二 ターした。全身麻酔下では中耳压が上昇するた めインピーダンスオージオメトリーによって判 定することはできない。よって筋電位を記録し なければならない，方法としては，三叉神経一 顔面神経反射（瞬目反射, blink reflex, 以下 BR)を用いた。上眼窩神経を電機刺激すると， 眼輪筋には潜時が約 $10 \sim 12 \mathrm{~ms}$ の R1, 潜時が 約 20〜 $40 \mathrm{~ms}$ の R2 とい5 2 つの誘発筋電位が 記録できるが，HFS 患者の患側においては， 正常では出現しない口輪筋やオトガイ筋からも $\mathrm{R} 1, \mathrm{R} 2$ に相当する筋電位が記録される4)5).こ れは病的共同運動を記録したものである．全身 麻酔下では正常人では BR は記録できないが， HFS 患者眼輪笳には R1 に相当する誘発筋電 位が記録され，同時に口輪筋やオトガイ筋にも 病的共同運動に伴う筋電位を記録できる4)6). この反射をアブミ骨筋の病的共同運動に利用し た、アブミ骨筋に直接電極を刺入できなくとも， それに近接して電極を配置すれば，加算操作を 加えなくとも筋電位を記録できる，術前にアブ ミ骨筋の病的共同運動が認められた 4 例には, 眼輪筋の誘発筋電位とともにとの潜時より短い 潜時のアブミ骨筋電位が記録できた，術前に表 情筋間には病的共同運動が存在するにもかかわ らずアブミ骨筋の病的共同運動が認められなか った数少ない症例の 1 例（症例 5 ）では眼輪筋 の誘発筋電位が記録されたのみでアブミ骨筋電 位は記録されなかったことから，術前の検査お よび術中の本方法が正しかったことを示唆して いると思われた。さらに，アブミ骨筋電位を記 録できた 4 例中 3 例は耳雑音を自覚していなか った症例であり, 耳雑音を自覚しなくとも多く の例で確実にアブミ骨筋に病的共同運動が及ん でいることを示すものである.

手術操作に伴らそれらの電位の変化を経時的 に記録すると，多くの例で血管を顔面神経から 
減圧する以前の頭蓋内操作の段階でアブミ骨筋 電位のみならず眼輪筋電位も消失した。直接の 減圧以前の手術操作で病的共同運動に伴ら異常 電位が消失したのは, 血管と神経の接触が物理 的に軽減されたためと推察した。しかしながら， この事実は術中にアブミ骨筋の病的共同運動が 消失したことの確証であると考えた。

MVD 術後にインピーダンスオージオメト リーを行らと, 術前に表情運動に伴ら異常なコ ンプライアンスの低下が認められた 54 例中, 術 後50例でそのコンプライアンスの低下が消失, 2 例で著しい減弱を示した. 術後所見が術前と 同様であったのは 2 例（3.7\%）のみであった. 耳雑音を自覚した例では, 全例耳雑音の消失と ともにアブミ骨筋の痤攣や病的共同運動は消失 した。つまり，耳雑音の有無にかかわらず，ア ブミ骨筋の痙攣や病的共同運動はMVDにより ほとんどの例で消失することを証明できたと考 えられた. MVD 術中に確認した圧迫血管は, 耳雑音の有無にかかわらず前下小脳動脈 (AICA) が最も多く, 次いで後下小脳動脈 (PICA), 椎骨動脈 (VA) の順である.すなわち, 圧迫血管の種類の差によって耳雑音が発生する か否かが決定されるのでは無いことが明らかと なった。

アブミ骨筋の病的共同運動による耳雑音はア ブミ骨筋性耳鳴と称され, 末梢性顔面神経麻瘏 後の病的共同運動に伴ってまれに起こることが あり，アブミ骨筋を切断すると消失したとの報 告がある778)。また，この麻痺後のアブミ骨筋 の病的共同運動により純音聴力検査にて低音域 の伝音性難聴を呈するとの報告8)97 がある. 我 々の症例の中で, MVD 術前に $0.5 \sim 1 \mathrm{kHz}$ に 10 20 dB の air-bone gap をもつ伝音難聴が術 後正常化した症例を 3 例に認めた。 これらの症 例の術前における伝音難聴はアブミ骨筋の痤攣 によって起こっていた可能性があると考えられ た。

HFS 患者のほとんどにアブミ骨筋の痙攣や 病的共同運動が起こっていることは, 今回の検
討結果から間違いないことである，耳雑音を自 覚するか否かには, 圧迫血管の種類や, 性別, 患側, 年齢, 罹病期間には全く差がなかった。 このことは, アブミ骨筋, あるいはその付着す る周囲組織の解剖学的あるい性理学的個人差 によるものと考えられよら910)が，そもそもア ブミ骨筋が収縮した場合の耳雑音の発生源を明 確にする必要があり，今後の検討課題であると 考える.

$$
\text { まとめ }
$$

1. HFS においてアブミ骨筋の痙攣と病的 共同運動は注とんどの症例（95\%）に認められ るにもかかわらず，耳雑音を自覚する例は $32 \%$ であった。

2. それらは MVD 術中操作, 術後に消失す ることを報告した。

\section{文献}

1) Jannetta PJ, Abbasy M, Maroon JC, et al : Etiology and definitive microsurgical treatment of hemifacial spasm; operative technigues and results in 47 patients. J Neurosurg $47: 321 \sim$ 328, 1977.

2）村上信伍, 松本 康, 丘村 熙, 他：アブミ骨 筋神経の空間的配列について. Facial N Jpn 2 : 39 42, 1982.

3）金 成，福島孝徳：顔面痤戀患者に打ける電気 生理学的知見一異常共同運動の意義と病因論に 対する考察一. 脳神経 $35: 289 \sim 298,1983$.

4) Møller AR and Jannetta PJ : Blink reflex in patients with hemifacial spasm. Observations during microvascular decompression operations. J Neurosurg Sciences $72: 171 \sim 182$, 1986.

5）板垣晋一, 斎藤伸二郎, 中井 昂 : 顔面痙敩に おける誘発筇電図の術中記録一発生機構に関す る考察一. Facial N Jpn $8:$ 143 146, 1988.

6) 板垣晋一, 斎藤伸二郎, 中井 昂: 顔面痙變の 電気生理学的検査に関する研究一原因診断にお ける有用性と発生機構一. 脳神経 $41: 1005$ 1011, 1989.

7）森満 保, 武馬成人：外傷性 facial spasm 拉上 び stapedial spasm 症例. 耳喉 $47:$ 79〜82, 1974. 
8）村田清高, 齋藤春雄 : 鐙骨筋の収縮による伝音 能率低下. 耳鼻臨床 $72: 1211 \sim 1217,1979$.

9）奥野秀次, 畑 裕子, 渡辺 勈: 異常共同運動 によるアブミ骨筋の収縮とアブミ骨筋性耳鳴. 耳鼻 $28: 7 \sim 13,1982$.

10）奥野秀次, 田中英和, 渡辺 勈: 外耳道電気刺
激によるアブミ骨筋の収縮とアブミ骨筋性耳鳴.

耳鼾 $29: 252 \sim 256,1983$.

$$
\left(\begin{array}{l}
\text { 別刷請求先 : 戸島 均 } \\
\text { T990-23 山形市飯田西2-2-2 } \\
\text { 山形大学医学部耳鼻咽喉科学教室 }
\end{array}\right)
$$

